\title{
Chapter Three Writing, not Speaking: Strindberg, Language, and the Self
}

\author{
What is said is always too much or too little: the demand that one should denude oneself \\ with every word one says is a piece of naiveté. \\ - Nietzsche: The Will to Power
}

An Author, who writes in his own Person, has the advantage of being who or what he pleases.

- Shaftesbury: Advice to an Author

'If your heart is heavy and you cannot speak, then write!', Strindberg encourages his sister, Elisabeth: 'Confide in the paper!' (III:41-2). To reject the possibility of speech and entrust himself to writing, to what he regards as the privacy and inviolability of the printed page, is so peculiar and yet essential an aspect of the presuppositions underlying Strindberg's practice that it has often been remarked, as has the teasing contradiction it implies between the author's inordinate shyness and the brutal self-assertion with which he permits his intimate life to circulate in print. Two images confront one another: that of a man whose childhood modesty caused him to conceal himself in a wardrobe when he undressed (a revelation to be made by his brother, Axel, which Strindberg disarms by anticipation in To Damascus III: 'We laugh now, when we hear he only wanted to change his underclothes in the dark wardrobe' (29:302)), ${ }^{1}$ and the uninhibited writer whose methods so easily leave him open to the charge of washing his dirty linen in public, as in A Madman's Defence: 'Now she's reached the briefs: she chooses a pair from which the tape has been ripped, and without betraying a trace of what she is thinking, puts them on one side. But I recognized them, since it was me who, frantic with desire, ripped them apart in the first assault' (MD:130-1). On the one hand, there is the writer who veils himself in words; on the other, the man who delighted 'in being able to tear off his clothes and go naked' (16:110).

Sustained by numerous anecdotal accounts which confirm Strindberg's partiality for indirect communication, even with those who were his daily acquaintance or the familiars of his house, ${ }^{2}$ the orthodox view thus emerges of someone in whom a fear of physical confrontation and an acute reticence 
in the face of friends and enemies alike rebound in a violent desire to 'attract attention in the world whatever the price' (I:168) through the writing wherein he exhibits himself. And yet, while evidence certainly exists to encourage Torsten Eklund in his supposition that 'there is hardly a writer who has stripped himself naked in his books as he has done, ${ }^{3}$ there lurks the germ of contrariety in the juxtaposition of this nakedness and the complimentary image of a man who removes himself to a distance where he cannot be observed or molested, writes, and then returns, adorned in language, to exact revenge on those in whose presence he felt unprepossessed.

This view is, of course, often anticipated by Strindberg's own self-scrutiny, which readily discloses the compensatory drives that literature is engaged to satisfy. Indeed, in the letter on writing to Siri von Essen, he explains his preference for the written over the spoken on precisely these lines. Firstly, he is inhibited in company and therefore it is 'this shyness which drives |him| to write' (I:186). Secondly, writing repairs the imperfections and slights of life and is often initiated and sustained by a desire for retribution: 'You are enraged by everything which is evil, base, and shabby', he tells Siri, whom he endows with his own sensations, 'but you cannot say so! Then write! And those to whom you weren't previously able to say all this, and who would have hated you for the truth, will applaud you!' (I:191). But it is also possible to find Strindberg acknowledging the likelihood that self-exposure might not be the candid procedure it at first appears. When Axel (in Playing With Fire, but the ubiquity of the name in the period 1887 to 1893 suggests a certain pseudonymity, or at least continuity of utterance) is called to account for always boasting about his wickedness, he replies, speculatively, 'Perhaps it's to conceal it?' (25:419), and a similar point is made in an exchange in Creditors:

Adolf: Do you know, I'm beginning to find your frankness painful. Tekla: And yet it was the highest virtue you knew - you taught it me. Adolf: Yes, but now it seems to me you're hiding behind this openness! (23:238-9)

Moreover, if to write for the press is a matter of appearing with the curtain raised on a bare stage (16:143), literature involves the donning of 'the impenetrable masks' (I:193) which conceal the writer. 'There will now be two plays one after the other. That is really my genre, since one doesn't need to be seen oneself' (V:355), he tells Bonnier, while at work on The Son of a Servant, where he wonders if being a poet is not really a matter of trying 'to get away from himself and invent another; is it the craving to dress up, is it modesty, the fear of selfsurrender, of laying bare one's shame?' (18:352). ${ }^{4}$

But beyond recognizing a tendency 'to make up a story which conceals the true outlines of the matter' (MD:234), Strindberg also entertains a more 
comprehensive distrust of language, and of spoken language in particular. This distrust is the perplexing context of his autobiographical project; indeed, it casts doubt on his attempt to represent himself in language, and is voiced so frequently, and with so remarkable a continuity of argument and imagery, that it is curious it should have provoked so little serious comment. ${ }^{5}$ And while it does not in itself explain Strindberg's fascination with autobiographical writing, it nevertheless serves to establish the ground upon which the continual inscription of life into the secondariness of written discourse takes place more adequately than mere shyness or a self-assertion that is fortified behind the armour of the word.

Notwithstanding the ease with which he customarily suggests that anyone can 'relate what they have lived' (III:41), Strindberg repeatedly maintains that human discourse is scarcely ever veracious but usually employed to mislead, conceal, and misinform. Whereas language in daily use is normally regarded as transparent and innocent, a clear mirror of the world or of its user's thoughts (as Emile Benveniste remarks: 'Pour le sujet parlant, il y a entre la langage et la réalité adéquation complète: le signe recouvre et commande la réalité: mieux, il est cette réalité), ${ }^{6}$ Strindberg regularly indicates a radical discontinuity between man and the world, and thought and action, which language does not mediate fully or faithfully. Indeed, language emerges as the very sign of difference, the mark of an unbridgeable fissure which it obscures but cannot conceal, and which is the token of the language user's alienation from a primary order of being in which language has no place. The apparent 'fullness' of words as bearers of meaning is therefore seen by Strindberg to mask an absence, either that of the reality which language displaces or screens, which was an important platform in his criticism in the 1880 s, or of truth, whose purity is perverted by the contaminated medium of conventional language, or even of the writer's own presence, which is evoked against the background of absence by means of a surrogate that does not truly represent him.

If this last possibility is clearly fundamental to the autobiographical enterprise, Strindberg originally formulates his misgivings about language in order to characterize its social function. That 'we are not what we seem' (27:67) is a constant complaint, from The Red Room to A Blue Book, and language provides both the instrument and the evidence of this general duplicity. Men use language 'solely with the object of deceiving one another' (48:1061), extending it like a screen, 'a web of hypocrisy and lies' (17:68), to conceal their real opinions and motives. People say what they do not think or hide what they ought to say behind 'the masking and dressing up of their upbringing' (16:109), and Strindberg often paraphrases the aperçu attributed to Talleyrand, 'La parole a été donné à l'homme pour deguiser sa pensée', in order to point the discrepancy between the notion that language is a faithful and 
adequate transmitter of fact and feeling, and its essential nature as the agent of invention, falsification, and untruth. In the story, 'The Reward of Virtue', the young Theodor takes refuge in 'a phrase, borrowed from a teacher, who had seen it quoted as Talleyrand's: "No, the purpose of language is to conceal people's thoughts"' (14:50), ${ }^{7}$ while the heroine of 'Short Cuts', after reflecting at length on the properties which make language so equivocal a possession, concludes: 'One strikes people dead with words, deceives and intimidates them with words, and a great man had written what books and newspapers so often quote, that language had been invented in order to conceal thoughts' (54:50).

Strindberg's conception of the origins of language is not, of course, unique. Karl Popper, for example, has recently argued that 'lying is a comparatively late and fairly specifically human invention; indeed... it has made the human language what it is: an invention which can be used for misreporting almost as well as for reporting, ${ }^{8}$ and during the 1880 s, at least, when Strindberg regarded the acquisition of language as a rite of passage from a state of innocence to the social world of what he termed 'The Public Lie' (Den offentliga lögnen), it is not difficult to discern a community of interest with both Rousseau and Nietzsche. Even in Strindberg's earliest writings, language denotes and facilitates a fall from pristine reality into the corruption of a world where illusion is fostered by words; with his departure from a natural state, the individual 'tastes the tree of knowledge' (54:199) and sinks into 'the half-darkness of fictions' (20:51), where he loses himself to art, the cognate of artifice, and Rousseau, too, imagines an unfissured pre-verbal innocence that is echoed in the language 'que les enfants parlent avant de savoir parler,' but which is irrevocably lost in social discourse, where it is as if 'un mal inéluctable pervertit la société et fait du langage cultivé l'agent infectant d'une duperie universelle... Mensonge, fiction, illusion forment le milieu même où évoluent les sociétés policées. Brillante comme l'or, la parole, de venue elle aussi monnaie d'échange, rend l'homme étranger à lui-même.'10 And just as Nietzsche remarked that 'the different languages, set side by side, show that what matters with words is never the truth, never an adequate expression; else there would not be so many languages, ${ }^{11}$ so Strindberg's linguistic scepticism evolves from a cultural critique that is indebted to Rousseau, into the radical questioning implicit in another recurring formula, namely 'that the different languages arose among the savage peoples in order to conceal the secrets of the tribe from the others; languages are thus ciphers, and the person who finds the key will understand all the world's languages' (45:190). Moreover, the image evoked here is 'the ancient legend of the Tower of Babel' to which Strindberg often refers, observing: 'People wished to storm heaven and seek the riddle of life, but God touched their tongues and called forth a general confusion, so that one man did not understand what the other said' (19:206). ${ }^{12}$ And hence, as Lars Gustafsson suggests, in his study 
of aberrant nineteenth-century philosophies of language, ${ }^{13}$ Strindberg also frequently appears to anticipate Fritz Mauthner or (especially in the Chamber Plays) the dramatists of the absurd in their misgivings about the capacity of language to represent the world or to convey one individual's perceptions to another. 'To exchange ideas is only a stock phrase, for no one exchanges his idea with another', he maintains, in A Blue Book: 'My best friend understands approximately 30 procent of what I say, and I can see that he misinterprets every word I have said' (46:46-7). Conversations are 'a Babylonian confusion which end in wrangling and the impossibility of understanding one another' (38:127), and the idea of correspondences, which Strindberg derives in part from Swedenborg and adapts to the pressures of his own thought, is related to an ancient crisis in which 'The One God divided everything in two and into antitheses' (47:551).

Thus the obsessive research into the nature and origins of language which Strindberg undertook in his last years becomes comprehensible in terms of a quest for an undivided language, the ur-language or Adamic vernacular that preceded Babel, in which there is a congruence between what is said and the language used to say it, a correspondence between word and referent, sign and signified. And like the Pietists, Swedenborg, and the Kabbala (which The Unknown regards as 'the wisest of all the books of wisdom' (29:169) when he reads from an account of the Tower of Babel in the Zohar), Strindberg sought the translucent immediacy of this lost primal speech in Hebrew, where he believed he could discern its features: 'One does not need more Hebrew than to be able to distinguish the article (ha) and the plural endings (im and ut) from the root, in order to hear echoes in a biblical concordance of a language which has probably been the same everywhere' (47:562). Furthermore, he suggests that visual correspondences indicate that writing also stems from a primary script. In a note 'On the Ur-Language and the Confusion of Babel', he reports his accidental discovery that Mongolian, normally written from right to left and from the top to the bottom of the page, 'resembled Arabic, particularly the old form which is used on Kufic coins' (47:531), when it is placed on its side. Moreover he likewise considers that 'the figures on the shell of a tortoise would have served the ancient Chinese as a model for the oldest written characters' (47:513), thus provoking the encouraging footnote: 'Anyone who wants to undertake comparative philology can buy the shell in Birger Jarl Arcade for 1 krona 50' (47:514).

The relevance of these apparently trivial speculations for Strindberg's concern to represent himself in language may be appreciated if the conception of language as something that conceals and misleads, instead of serving to enlighten and communicate, is recognized at the heart of one of his primary categories, 'the law of accommodation', which he formulates in The Son of a 
Servant. Previously, in the polemics of The New Kingdom and Like and Unlike, he had argued that 'by living together, one is forced to place restraints on oneself that only long to be broken; conventions, politeness, etiquette, all that is necessary, but it is a terrible necessity, because it is falsehood' (16:90). He had been concerned with the public lie and enquired, like Max Nordau, whose popular exposure of late nineteenth-century hypocrisy and humbug, The Conventional Lies of Our Civilisation, he briefly considered 'the Holy Writ' (IV:9), how

... if we are born in lies and grow up surrounded by lies; if we are obliged to lie every time we open our mouths in public, or come in personal contact with any of the political and social institutions of the day, if we are in the habit of always speaking and acting differently from the way we feel and think, of enduring the perpetual contradiction between our inward convictions and the outward phases of life as a matter of course, of considering hypocrisy as worldly wisdom and duty and sincerity as extravagance... it is possible to retain a sincere and upright character? ${ }^{34}$

Now, in turning inwards to examine himself, he comes to see how all social intercourse prevents one from being (to take the phrase literally) oneself, since 'when one talks to someone one adapts oneself slightly in their favour, when one talks to another, one makes a concession to them, and if one did not do this but said exactly what one thought, the conversation would end with everyone spitting in one another's face and walking off, never to meet again' (19:177-8). Insertion into the circuit of linguistic exchange is to lose one's self. Within the symbolic order of language, in the act of speaking, one becomes another, or as many others as one converses with. Through his self-study, therefore, Strindberg discovers not character but characterlessness, and when he regards the contradictory images of his past self at the end of the first volume of The Son of a Servant, he discerns not a single, unique presence, but a multitude of personae assumed according to circumstance and company:

That was the law of accommodation, which Johan did not know about. People were like that there was an instinct to adapt oneself, which rested partly on calculation and partly on unconscious or reflex actions. A lamb to one's friends, a lion to one's enemies.

But when was one being true to oneself, when was one false? Where was the self-which supposedly constituted one's character? It was neither here nor there, but in both places at once. The self is not any one thing; it is a conglomeration of reflexes, a complex of instincts and desires which are alternately suppressed and unleashed! (18:218) 
That linguistic competence involves the ability to use language to sustain the duplicity social life requires, is an idea Strindberg never relinquishes. In a late fragment, headed 'The Logic of Conversation', which expands upon a section in A Blue Book entitled simply 'Logic' (48:1061), he argues that 'for the most part opinions are rooted in the flesh' and describes how any overheard conversation will shock a listener by the way in which the speakers accommodate themselves to each other's point of view. ${ }^{15}$ Such scenes occur or are evoked in numerous texts (Alone, The Ghost Sonata, A Blue Book) where a tension between speaking out and remaining silent is a central motif, and increasingly, as the title of a late Vivisection suggests, character is confirmed in Strindberg's mind as a series of roles demanded by successive situations: 'N'est-ce pas que l'on s'adapte à chaque instant aux hommes et aux choses, que la réalité si variable et oscillante nous fasse varier, et que nous jouons la comédie de la vie sans la savoir?' (VR:126). Indeed, the deviousness inherent in the social use of language is depicted as so prevalent, unconscious, and essential a part of the 'accommodating complaisance, without which intercourse becomes impossible', ${ }^{16}$ that Strindberg's reaction appears excessive. There seems no reason why he should not accept his insights with the scepticism expressed in a letter to the poet, Verner von Heidenstam: 'My writing: a seeking after the truth! Idiotic in itself perhaps, for the truth is only conventional!' (VII:92). And yet the reverse is true. Although the mendaciousness of the medium in which it is formulated seems to undermine the discourse of the self at which he aims from the outset, it is impossible to mistake the way in which, like Rousseau and his claim that 'Ma fonction est de dire la vérité', ${ }^{17}$ Strindberg nevertheless repeatedly presents himself as the custodian of the truth which words are supposed to belie; as he informs Harriet Bosse: 'When you talk or write to me, remember it is to a man who cannot, who dare not say a word which is not true!'18

The Son of a Servant is clearly a key text in establishing this reputation for candour and probity, and Strindberg's project obviously invites comparison with Rousseau's. It is not, of course, difficult to discern an affinity between the belief 'that by crowding together and mingling their existences with one another's, civilized people... no longer live for themselves but only have their being in what others think of them' (16:74), which develops into 'the law of accommodation', and Rousseau's theory, advanced in the Discours sur l'origine del'inégalité (but no less anticipatory of the view of the self which the Confessions present), that 'le Sauvage vit en lui-même; l'homme sociable, toujours hors de lui ne sait vivre que dans l'opinion des autres, et c'est pour ainsi dire, de leur seul jugement qu'il tire le sentiment de sa propre éxistence. ${ }^{19}$ As Sven-Gustav Edqvist has shown, in his study of Strindberg's anarchism, ${ }^{20}$ much of his early thinking is pre-figured in Rousseau's account of man's transition from the state 
of nature to civilization, where 'Etre et paroître devinrent deux choses tout à fait différentes. ${ }^{21}$

However, the fundamental affinity between Rousseau and Strindberg lies firstly in the way in which the formulations of such texts as 'On the General Discontent' are as intimately related, in substance and imagery, to the most personal aspects of the experience related in the autobiographical volumes, as Jean Starobinski has demonstrated is the case with the Discourses and Confessions: 'A tort ou à raison, Rousseau n'a pas consenti a séparer sa pensée et son destin personnel';22 and secondly, that the role of language in the presentation and distortion of the social self promotes a desire to commit themselves to language in a discourse appropriate to themselves. In fact Rousseau's presence shadows any discussion of Strindberg's decision to write the narrative of his life, and it is remarkable that while his influence on Strindberg's social and political thought has often been surveyed in detail, there have been few more than cursory discussions of their intellectual and emotional consanguinity, and this despite the role which the Confessions undoubtedly have as part of the constitutive literary intertextuality of Strindberg's life, and of The Son of a Servant in particular. ${ }^{23}$

In the utopian fable, 'The Isle of the Blessed', the text in which Strindberg comes closest to repeating the received message of Rousseau's account of the rise of civilization, language is again shown as the means of transforming what is into what is not: 'The children discovered that answering yes when one ought to answer no brought one advantages, such as rewards, or freedom from punishment, and therefore the lie began to flourish' (11:94-5). Similar words are used to introduce this discovery, now presented as a general law, into The Son of a Servant: 'One of the earliest discoveries of the awakening intelligence is that a well-placed yes or no can reap an advantage' (18:16). But what lends it authority on this occasion is its corroboration by a primal scene of truth and appearance which, like the Lambercier episode in Book One of the Confessions, is placed at a strategic point in the narrative of Strindberg's life, initiating much that is to follow and reverberating throughout the entire body of his work to issue in the thought and imagery of the Chamber Plays and the unfinished fragment, Armageddon.

In fact the scene recounts a paradigmatic event which, whether true or false, is at the core of the autobiographical narrative. And yet, even granted the chagrin of a childhood injustice and the immediacy of direct speech, which is used here in the book for the first time, its resonance seems, on first reading, disproportionate to the occasion. In a short dramatic episode of only three pages (but from which it is difficult to exclude all knowledge of the slightly longer passage in which Rousseau, at a similar point in his autobiography, is mistakenly accused of breaking Mlle Lambercier's comb), Strindberg describes 
how Johan is unjustly punished first for denying that he had drunk from a bottle of wine which he had not even touched, and again for denying he had lied in making his original profession of innocence. What rankles most, however, is not the punishment itself, but the way in which the child has been compelled 'to confess to something he had never done' (18:18), an outrage which rekindles the narrator's ire and prompts him to describe the family as that 'splendid moral institution... where innocent children are tortured into their first lies' (18:18).

And yet this scene, which is reinforced some fifty pages on (18:68) by the comparable episode of the iron screw nuts, where Johan is once again beaten into confessing he has stolen something he has in fact only come upon by chance in the street, is constitutive both of the work in its entirety, and of the life which sustains it. Sometimes evoked directly, but more often, as in The Red Room, 'A Child's Saga', or The Burned House, leaving its trace upon the surface of another text in the form of an analogous incident that has taken place under the intense pressure of its repressed emotion, ${ }^{24}$ this primal scene of unmerited punishment forms part of the network of mnemonic material in an opening chapter which is, like the first book of the Confessions, where the Lambercier episode is similarly complemented by the later scene of the stolen ribbon, which concludes Book Two, ${ }^{25}$ at once 'le premier acte du drame, et le drame tout entier. ${ }^{26}$ As René Bourgeois has observed, in an essay, 'Signification du premier souvenir', in which he makes much of the punitive scene which opens the autobiographical narrative of another of Strindberg's French precursors, Jules Vallés, 'La plupart des premiers souvenirs sont dangereusement significatifs et révélateurs non d'une réceptivité passive mais d'une volonté de reconstruction systématique, ${ }^{27}$ and the account of Strindberg's earliest years in The Son of a Servant is already a kind of retrospective prolepsis. It not only performs its ostensible purpose, which is the recuperation of the past; it also delineates the features of a destiny that will be continually repeated, firstly in the developmental, genetic model of the 1880s, in which the man grows from the seeds of his physiological, psychological, and environmental inheritance, into the person he was always destined to be (or, as the first volume concludes, to remain: 'And thus he stepped out into life! To evolve and develop, and yet to remain forever the person he was' (18:219)) and then, when Strindberg renounces his Naturalism and no longer wishes to regard himself as continuous with nature, as emblematic of the fate allotted him in this, the terrestrial, phase of his drama.

Both these views are implicit in the episode. Seen from the perspective he employed in the mid-1880s, the scene projects an image of childhood innocence savagely abused in an environment that, ironically, predicates truth as the paramount virtue: 'In Johan's home truth was worshipped' (18:68). It 
represents the moment of passage recorded in 'The Isle of the Blessed' and is restated many years later by Gerda, in The Pelican, when she observes: 'People call one wicked if one tells the truth... so I learned to say what I didn't mean, and then I was ready for life' (45:246). All the authority of the psychological and sociological discourses employed in the book combine to pin-point the critical moment when the child is expelled into a society that accepts the evidence of appearances before the testimony of truth. Quite simply, when he speaks the truth Johan is heard to lie. His accusers disregard the words he uses to represent himself and so fail to judge him as he knows himself to be, while his innocence as yet denies him access to that fluency of speech which would enable him to appear as others see him.

The traumatic nature of the episode is also evident from the way in which it recurs throughout Strindberg's writing, from the errand boy in The Red Room, 'who was far too young and innocent to be able to get himself out of a fix with a lie' (5:320), and who is beaten because he tells the truth, to the Son in The Pelican, who reminds his mother of how, when he told her 'what I saw in the abode of sin, you said it was a lie, and you struck me as a liar' (45:265). But even within the confines of the emphatically Naturalist discourse of The Son of a Servant, there are intimations of another reading of the text submitted by life, which will eventually come to preoccupy Strindberg with increasing urgency. When the episode ends, Johan has been cast in a role that does not suit him; seen a fissure open up between himself and others, and between appearance and reality; encountered the ambiguity of right and wrong; and become an object of suspicion on the periphery of society, the eventual outcast, Ishmael:

He felt like a criminal. Punished for lying, which was so abominated in the house, and for theft, a word never even spoken there. Deprived of his civil rights, regarded with suspicion, and despised by his brothers because he had been caught. All of this, together with the consequences, which were very real to him, were nevertheless based upon something that did not exist at all, his crime. (18:19)

Not unnaturally, too, the dilemma nurtured in the wake of this scene provokes in Strindberg a continual questioning as to whether or not he is guilty, and if not who is, and if so in what way since the punishment seems, initially at least, to precede the crime. And hence, as Martin Lamm has pointed out, ${ }^{28}$ The Son of a Servant already contains the notion that 'life was a penal institution for crimes committed before one had been born' (18:39), in which the many later, postInferno scenarios of guilt, suffering, and punishment, and the many figures of history and myth with whom Strindberg finds correlatives for the shape and significance of his destiny, are clearly prefigured. The idea haunts many texts, sometimes discretely and impersonally, as in the description of Theodor, 
in 'The Reward of Virtue', who was sometimes gloomy and ruminative, and felt life was not as it should be. It seemed to him that some unparalleled crime must have been committed in the past, and that it was now being concealed under a mass of deceptions' (14:58). More frequently, however, its implications are personal, as when The Unknown senses how 'Fate is elaborating her plot, once again I hear the gavel fall and the chairs pushed back from the table the sentence is pronounced, but it must have been decided before I was born, for already in my childhood I began to serve my punishment' (29:53), and it remains central to one of Strindberg's last attempts at elucidating the pattern of his destiny in Armageddon, where the nature and function of language are once again a major consideration.

As Walter Berendsohn has suggested, ${ }^{29}$ Armageddon may well form a kind of prologue in heaven to the collected volume of Strindberg's autobiographical sequence as he conceived it towards the end of his life. It can certainly be read as such. Not only does it contain a prophetic account of a destiny which in its particulars seems remarkably like a retrospective summary of the life Strindberg saw himself as just completing, thus suggesting that its course had been artistically arranged, or plotted, from the outset (hence the statement: 'His future fate... is already written' (54:156)); it also breaks off shortly after the birth of the protagonist, Skugge, at roughly the point at which The Son of a Servant commences with the chapter 'Afraid and Hungry'. Moreover, in describing Skugge as someone who 'did not want to be in the way and who was not allowed to talk' (54:162), it even repeats the familiar description of Johan as 'frightened of being in the way' and unable to 'go anywhere without being in the way, without saying a word that did not disturb' $(18: 8,14)$.

The fragment relates how Skugge (cf. Sw. skugga = shadow), initially called Fröjdkyss (lit. 'Kiss of Joy'), becomes a shadow of his former self once he 'learned to say what he did not think' (54:152), and how he is therefore expelled from a harmonious realm of 'truth, justice... purity and innocence' (54:148-9) back down into a world called Dimona (cf. Sw. dimma $=$ mist), where everything is 'ugly or false', 'distorted and counterfeit' (54:155). There he makes 'the child's first great discovery in the art of life: how to avoid trouble by dissimulation' (54:162), and the narrative ends abruptly with a scene in which Skugge 'sat in his corner and heard how the others said what they did not mean and how they spoke differently to different people and on different occasions. This, he realized, was what was called lying' (54:163).

Armageddon thus depicts the sentence passed before birth on a character whose kinship with Strindberg's earlier self- images is unmistakable, and then describes his subsequent banishment to a place which is recognizable as the 'penal institution' of The Son of a Servant, but which is now portrayed in the imagery of Black Banners, the Chamber Plays, and A Blue Book, as 'a prison 
and a madhouse with many names' (54:156).$^{30}$ It is a place of illusions, ' the world of delusion' (46:34 - villornas värld), where men resemble sleepwalkers, and nothing is what it seems but 'perverse, imperfect, and crazy' (46:129), a world where 'we really live not in reality but in our ideas of reality' (46:169), and 'even the man who tries to tell the truth with an upright mind, gets entangled in inherited lies and is trapped' (54:156). Moreover, what specifically distinguishes this world from the pre-natal paradise from which Skugge is expelled, a realm where everything is 'what it pretends to be' (44:75), is language, with its capacity to deceive. And here Strindberg's own earlier intimations of a higher existence are realised in a terminology that now owes much to Swedenborg. ${ }^{31}$ Like the Chamber Plays, Armageddon relies heavily upon the doctrine and topography associated with the Swedenborgian notion of Lower Earth, to which men pass at death, and where they gradually lose the ability to mask their thoughts and feelings. In time, therefore, outer appearance becomes a mirror of the individual's inner reality, and the prize of moralist and autobiographer alike, his true self, is revealed.

Yet more pertinent to Armageddon, however, is the sanction Strindberg discovers elsewhere in Swedenborg for his own misgivings about language. For in the sections of De Telluribus devoted to the inhabitants of Jupiter and Mars, ${ }^{32}$ Swedenborg describes a type of wordless communication which Strindberg adopts and bestows upon Skugge's companions, Pärlskön and Havsdroppe: 'They spoke but little with words, but with glances and smiles' since 'they could see one another's thoughts with their eyes, and they could also show what they were thinking; their eyelids did not move, either to conceal something or in pretence' (54:151). Effected mainly by means of facial expression and adequate because of the correspondence between what Swedenborg termed interior and exterior speech, this wordless communication can dispense with the mediation of the spoken word since the inhabitants of Jupiter are unable to 'show a face at variance with the mind... because they never speak otherwise than they think. ${ }^{33}$ Indeed, Swedenborg's account of the development of language suggests that 'the very first speech on every earth was speech by the face' and that it is only because men learned to lie that verbal speech became a necessity. In what reads as a paraphrase not only of Armageddon but of Strindberg's conception of language in general, Swedenborg argues:

that verbal speech could not have been used by the Most Ancient people, since the words of a language are not imparted immediately, but have to be invented and applied to objects; which it requires a course of time to effect. So long as sincerity and rectitude prevailed among men, such speech continued; but as soon as the mind began to think one thing and speak another, which was the case when man began to love himself and 
not the neighbour, verbal speech began to increase the face being either silent or deceitful. ${ }^{34}$

Not surprisingly, such ideas appeal to Strindberg, who finds them reinforced at the end of the century by Maeterlinck's collection of essays, Le Trésor des humbles where, in contrast to speech, which cuts man off from reality, silence is described as the language of the soul and the means of true communication. To Maeterlinck, who on at least one occasion amended Talleyrand's aperçu by observing that speech is all too often not the art of concealing thought, but of stifling it, so that there is nothing to conceal, silence is eloquent, revealing, and non-concealing, and permits what is within a person to rise to the surface where it becomes visible to the interlocutory glance, and Strindberg, who began to translate Le Trésor des humbles as a gift for Harriet Bosse, likewise often regarded silence as the discourse of virtue in his later works. 'I prefer silence', the loquacious Hummel claims, 'then one hears thoughts, and sees the past, silence cannot conceal anything... which words can' (45:190), while Strindberg himself observes: 'One ought never to speak, only signal what is most vital to meet the needs of life. And when one comes together, one should hear music' (48:917).

These convictions seem to place not only speaking but even the writing of literature in doubt, and Strindberg does in fact remark that 'the godly do not portray their marriages, and they write neither plays nor novels' (47:735). But his profoundly ambiguous relationship to language, spoken and written, does not admit so neat a conclusion. The possibility that language does not convey a perfect representation of the truth may in any case be experienced as an affront to propriety. A classic instance of this occurs in Swift's account of the Houyhnhnms, where Gulliver, 'having occasion to talk of lying and false representation', encounters a problem in conveying what he means to his master:

... it was with much difficulty that he comprehended what I meant: although he had otherwise a most acute judgement. For he argued thus: that the use of speech was to make us understand one another, and to receive information of facts; now if one said the thing which was not, these ends were defeated; because I cannot properly be said to understand him; and I am so far from receiving information, that he leaves me worse than in ignorance; for I am led to believe a thing black when it is white, and short when it is long. And these were all the notions he had concerning the faculty of lying so perfectly well understood, and so universally practised among human creatures. ${ }^{35}$ 
With Strindberg, too, the possibility that language may be used to say 'the thing which was not' seems to violate not only virtue and truth but also the categories of order and disorder, and justice and injustice, so frequently associated with them. Moreover, since disorder suggests the idea of dirt, the debased work in which verbal language is an unfortunate necessity is readily linked with the notions of purity and filth which are never far removed from Strindberg's attention, as indeed, they are not from Swift's. 'He began to disturb the regulations,' Pärlskön says, of Skugge, 'he learned to say what he did not think, but his falseness could not be concealed, for whoever tells the truth has both his eyes in equilibrium like the balance on a set of scales' (54:152). Hence he is excluded from the company of his fellows 'for his breath stinks sourly and he sweats as if from the effort of concealing his thoughts' (54:153). Thus he is eventually condemned 'to lie in foul smelling filth' (54:160).

In the significative system elaborated in Armageddon, therefore, verbal language is specific to the fallen world of dirt (smuts), falsehood (osanning), lies (lögn), and excrement (träck), whereas the purity of wordless communication is peculiar to a situation of truth (sanning), purity (renhet), innocence (oskuld), and justice (rättvisa) as it is portrayed in the opening scene of the fragment, where a number of Strindberg's most constant and deeply-rooted desires are adumbrated. Thus, like the Stockholm archipelago or Switzerland which, according to Strindberg, have their 'great glorious nature, and therefore need no surrogate' (16:166), the purity of this landscape requires no art, nor any other kind of mediation. 'He who has nature needs no art' (4 7:656), he maintains, some twenty years later, and any violation of what he understood to be the order of nature always appeared to Strindberg to be, like Axel Borg's optical transformation of the archipelago in By the Open Sea, 'something monstrous' (24:153). This landscape also reflects his abiding preference for plants over animal life. 'It is mainly in the world of plants that I have found perfect beauty' (47:606), he asserts, at about this time, and the rarified atmosphere of the world from which Skugge falls, which is inhabited only by non-carnivorous animals and birds who discharge their waste products into the air through their lungs 'in a cleanly manner' (54:148), denotes a recoil from the brutish facts of eating, excreting, and reproducing that is similarly articulated in The Ghost Sonata and The Pelican. For almost invariably, the notion of smuts, of dirt and disorder, is associated in Strindberg's imagination with 'excrement, nourishment, cooks and rotting vegetables' (37:207), and with sexuality, as when Johan, coming directly from a scene with his mistress to join his sisters in the country, wonders 'what the word filth (smuts) means?' (19:127), and traces the disturbing image of sexual love it evokes back, by way of his sister, Anna, to his mother. Moreover, while Strindberg regularly attempts to discriminate 
between marriage as ren (clean, pure) and the temptations of the bachelor as smuts, the distinction frequently collapses ('to me bachelor life is filthy. Family life is finest - and yet, it's even filthier, when one roots around in it!' (XI:100)) and his later works indicate that for him, as for Max, in Gothic Rooms: 'There are times when I believe... that our human souls have had to creep into animal bodies. We behave like animals, we kiss with the same mouth which takes in food, and we make love with an excremental organ' (40:195).

Since language, both verbal and non-verbal, is essential to this two-edged current of desire and disgust, and since it is the medium in which Strindberg has elected to conduct his life, the tensions and taboos generated here are of crucial importance to his undertaking. As the Tempter comments, in To Damascus, it is precisely the most purely intentioned of wordless acts which occasions the situation from which language recoils. 'I have never understood,' he remarks, how a kiss, which is an unborn word, a soundless speech, a silent language of two souls, can by a sacred act be transformed into... a surgical operation, which always ends in weeping and the gnashing of teeth' (29:340). Conversely, as Strindberg argues, in $A$ Blue Book, in a section which summarizes a situation depicted many years earlier in 'Short Cuts', when the apparent conversation of the young lovers, Tekla and Robert, in fact conceals a passionate wordless discussion, language also becomes the screen behind which the discourse of desire unfolds in silence: 'The spoken word has frequently become a fig leaf which conceals shame. When you ask: "Do you love me, will you be my wife?" do you know what you are touching on then? You are really asking her, if you first may kiss her, then... and then... and then' (48:875). Thus, in making his famous enquiry, 'Will you have a little child with me, Miss Bosse?'36, Strindberg may be discerned shortcutting the preliminary stages of a sequence that is normally concealed behind the verbal fig leaf. Indeed, the latter is actually evoked in Creditors, where Gustav describes how Tekla and Adolf 'creep behind the fig leaf, play brothers and sisters, and, as their feelings become increasingly carnal, invent a relationship for themselves that is more and more spiritual' (23:207), a notion that is also present in 'Short Cuts' where Tekla asks Robert if 'their souls are brothers and sisters' and he confirms 'the invisible bond' between them. When she claims 'it seems to me, as if every word you spoke was my own thought' (54:43), they seem to be enjoying the silent communion that Strindberg later extols. However, their dialogue is not ethereal but a cloak to conceal their unspoken desire. Robert clothes the discussion in 'a veil of the wonderful... so that they moved quite unconstrainedly beneath the light veil. They spoke freely, as if behind masks' (54:43-4), moving gradually towards 'the burning words' (54:45) which pluck their veil aside to reveal, in the common memory of a youthful kiss, the nakedness of their present desire. 
Thus the very silence which in theory constitutes Strindberg's ideal proves in practice to be immoral. For it is party to the veil of lies and hypocrisy which sustains social life, those 'silent agreements, public secrets which keep society together' (16:91). In The Son of a Servant he relates how Johan 'had learnt to speak the truth ... took a brutal pleasure in saying straight out what everyone was thinking in the middle of a conversation where people were dallying with the truth' (18:217), a reaction which persists with Strindberg to the end. In The Pelican, the Son recognizes 'a duty to speak out' (45:246), for as the Student insists, in The Ghost Sonata, 'by remaining silent for too long, stagnant water accumulates and things rot' (45:208), and as Strindberg informs Harriet Bosse, since silence implies complicity in a collective deception with both private and public ramifications (on this occasion, as on so many others, he is referring to marriage), he is always compelled to distinguish himself, to make himself heard. 'A volcano of repressed opinions takes shape and it has to explode', he tells her (XIV:121), for otherwise (as The Dead Man remarks, in The Isle of the Dead) he will explode himself: 'Oh, that I can't keep quiet any longer, but I have stayed silent for thirty years, until in the end I got so full of falsehood I was on the point of bursting. ${ }^{37}$ Confronted by a society that 'wanted to hush him up' (54:71), he consequently evolves the apocalyptic notion that were the true word spoken in 'the simple, raw language of truth' (54:227), then 'society would fall apart' (17:68). This is already anticipated in his early play, The Freethinker, with its defiant conclusion: 'Sooner may heaven and earth collapse, than a word of the truth be denied!' (1:57), but it assumes a particular meaning in the scenes of undressing (avklädning) or unmasking (demaskering) in which the later works abound, where the word spoken in truth kills. 'Words are forms of energy of unparalleled strength' (46:193), Strindberg asserts, and the Student's deadly outburst to the Daughter at the end of The Ghost Sonata is conceived as a speech act in which ' $\mathrm{He}$ murders her with words'. ${ }^{38} \mathrm{~A}$ similar process is depicted in Creditors, where Gustav talks Adolf to death, and it may be related to another recurrent belief, which again serves to link the autobiographer with the recorder of sins in the Book of Life, that when a man achieves precise selfknowledge, that is, when he sees himself (or as Strindberg may express it, his ghost or fylgia (23:268)) as he is, he dies: 'But when one has seen oneself, one dies!' (45: 139). Or as the Hunter muses at a graveside in The Great Highway:

'Here rests' - yes, I knew you

but you never came to know yourself...

and you; all your life you were disguised,

your long heavy life;

and when I stripped you naked, you died! (51:77) 
Strindberg thus regards the language he uses as both deadly and pure, and confronted by another, his immediate desire is often, like The Unknown's response to the Doctor in To Damascus, 'to speak a pure language and blow him up' (29:42). But this involves the use of 'coarse words... such words which most truly, that is to say most rawly reproduce thought' (17:68), something his sensitivity to the role of language as a carrier of impurity and sexuality will cause to haunt not only the reception of Getting Married (which is in any case an outspoken linguistic act from which he eventually tries to exculpate himself), but any text which seeks 'to lift the curtain' (17:67) and speak the truth. Lifting the curtain, moreover, is similar to removing the fig leaf, and like Strindberg's ambivalence about exposing himself in literature, the medium in which he performs this public undressing is also equivocal. It both entices and disgusts him as 'a raw and repulsive occupation (V:121), and the intermittent attraction of a scientific discourse, preeminently of chemical formulae, may well satisfy a wish for a language that is immune to the contemporary accusation that his writing was 'the product of a fantasy, which finds pleasure in wallowing in filth. ${ }^{39}$

However, the danger of pollution is reduced because Strindberg so pointedly avoids immediate verbal intercourse. The raw, murderous language he espouses is not spoken but written in solitude on the virginal purity of the white and silent page to which he confides what he is unable to say. These are the terms on which he constantly insists when he describes writing; they elaborate the scene in which the page is inscribed with the life of its scriptor. Although one writes what one does not say, he informs Siri, 'the secret is nevertheless kept... the whole art consists in inventing the impenetrable masks and - in keeping silent. Silence is holy. What one has once related before it has been put down on paper is lost' (I:193), a prescription which is echoed in the passage in A Blue Book in which he exonerates himself from the indiscretions of the press which he periodically accuses of betraying the privacy of his written discourse:

I confided it to the silent, printed word on the white page. It was a confidential communication; and the person who betrayed it was a traitor.

Our books are made to be read in silence, to be whispered in one's ear; but the newspaper always speaks aloud, it shouts the secrets out, and therefore bears the guilt. (48:941-2)

Both Martin Lamm and Torsten Eklund have, of course, focused their attention on these and similar passages, ${ }^{40}$ and it would be tempting to share their perplexity over the apparent disingenuousness in what seems an attempt on Strindberg's part to disclaim responsibility for his own indiscretions by transferring the guilt incurred in making them onto other writers, whose medium is nevertheless also the printed word. And equally, the distinction 
between writing and speech which he consistently sets up, also ask to be considered in the terms evolved by linguistics to explain the difference between the two modes of language use. Accordingly, Strindberg could be said to reject what Saussure calls 'the natural bond, the only true bond, the bond of sound', 41 in favour of the surrogate permanence and stability offered by the graphic form of words. Strindberg prefers the solitary, secondary, invented mode of writing, which arrests, fixes, abstracts from, and supplements experience, a mode of communication which eschewes the immediacy and disorder of dialogue, and which is characterized by a double absence, or occultation, wherein the reader is absent from the writing of the book and the writer from its reading, to what is regarded, if only because of the anteriority of speech to writing in the individual's life and in history, as the primary, natural, even divine mode of communication, in which the voice, borne by the breath, and guaranteed by facial expression, gesture, tone, and inflection, signifies the presence of the speaker and of his companions to himself and to others, in an interlocutory situation that binds voice and ear in the here and now. For speech proceeds from an evident context, both in terms of the perceptual surroundings and the cultural and historical background the speakers have in common. It is, moreover, interruptable, an exchange, and in its intersubjectivity, it promises an essential and immediate proximity of voice and being. ${ }^{42}$ It also appears to have the virtue Strindberg denies it, in being immediately verifiable or, at least, open to question, since the speaker is promptly accountable for what he says (they are his words, unless he says otherwise) whereas writing, what Vygotsky terms 'speech without an interlocutor, addressed to an absent or an imaginary person or to no one in particular ${ }^{243}$ is spatially and temporally removed from its occasion, and is often placed under the aegis of death (presided over as it is in Plato's Phaedrus, by Thoth, the Egyptian God of writing and inscriber of accounts before the Last Judgement), a monument to pastness not only in the posthumous perspective of the autobiographer but also, according to Paul Ricoeur, in the response to all writing: 'to read a book is to consider its author as already dead and the book as posthumous. Indeed, it is when the author is dead that the relation to his book becomes complete and, in a way, intact. ${ }^{34}$

In practice, however, the situation is more complex than a straightforward dichotomy admits. Strindberg is in any case suspicious of the notion of a full and present speech, and of a presence immediately recoverable from a spoken discourse that is transparent and innocent. All too often people do not commit themselves to their utterances, and in place of the noisy, soliciting, impermanence of the spoken word, in which the speaker dissipates himself, he therefore resorts to literature in order to reappropriate the presence which eludes him in speech. If the latter is where he is dispersed and misrepresented, writing is where he coheres, and in contrast to a spoken discourse in which 
the changing motives of the various participants determine the intermittent flow of the utterance, the written is where the discourse seems to pass under the uninterrupted control of its producer, or at least, to provide him with the semblance of control: 'Since I still cannot say coherently as much as is written on this sheet of paper', he writes to his early benefactor, Rudolf Wall, 'I have taken the liberty of writing' (I:228).

But if in doing so he withdraws from what Ricoeur calls 'the bodily support of oral discourse, ${ }^{45}$ this does not mean that the writing he produces is disembodied or that it becomes 'more spiritual in the sense that it is liberated from the narrowness of the face-to-face situation. ${ }^{36}$ Strindberg is in fact not so considerate or self-effacing as to abandon his texts to the anonymity that many textual critics regard as the domain of the written. Although he ordinarily refuses the facile $\grave{a}$ clef identifications that his contemporaries often made between themselves and the characters of his books, and eventually argued the virtue of 'the protective veil of pseudonymity' employed by 'the writer of folk songs, who effaced his own self and lived only as the echo of a song' (47:647), he felt the duty of the Kierkegaardian witness of truth (sannhedsvittne) to be responsible for his words, answerable for them, and discernable in them. What the reader should hear, in short, if not perceive, is 'a heart beating in every line' (II:42).

The ways in which Strindberg accomplishes this are various. A text may, as Sverker Hallén has demonstrated, be at once stridently contemporary in its literariness and a private message, directed to a single addressee. Thus the French edition of 'Deranged Impressions', Sensations detraquées, incorporates a passage which reads on one level as an exercise in a fashionable fin-de-siècle literary code of associative symbolism, and on another, as a cipher of allusions in which he warns his dubious Parisian benefactor, Willy Gretor, against interfering in his private life. ${ }^{47}$ A situation may also arise, especially in relation to Siri von Essen or Harriet Bosse, where Strindberg uses his writing to conceive an interlocutress who was simultaneously the subject, reader, and even the actress of the roles attributed to her. As he tells his colleague, Geijerstam, Siri will repeat the role in which he has cast her: 'My wife will only play the role which is written for her, and which suits her' (VII:166). For what he often seeks to accomplish by writing is a distribution of roles in which he does not merely try to re-present himself and render his self visible; he also contrives the immediate absence of the other and his or her presence, both in the substance of the discourse and as its eventual reader or actor. As a passage in Alone demonstrates, for Strindberg writing is speech, a kind of dialogue, but one more ample and representative than circumstances ordinarily permit:

I perceive my own thoughts as spoken words; I seem to be in telepathic contact with all my absent acquaintances, friends and enemies; I carry on 
long orderly conversations with them, or resume old conversations held in convivial company, in cafes; I oppose their opinions, defend my point of view, and I am much more eloquent than when I am in the presence of listeners. (38:177)

As is the case with Rousseau, for whom writing provides the necessary substitute for the improvisations, embarrassment, and imperfections in which speech involves him, this passage illustrates that the written word affords the once aphasic Strindberg a compensatory form of eloquence in which the features of the unsuccessful encounter are recomposed in retrospect. Lacking the ability to improvise a rapid response, gauche and inept, and all too sensitive to those factors, spoken and unspoken, which impinge upon him in the interlocutory situation, Rousseau is repeatedly discomfited when he commits himself to speech and thus concludes: 'Le parti que j'ai pris d'écrire et de me cacher est précisément celui que me convenoit. ${ }^{48}$ Likewise it is in writing that Strindberg becomes master of himself and of his life. Only he does not intend to hide himself: there, as so many commentators follow him in remarking ('This shyness drives me to writing' (I:186)), he is not shy.

But shyness (blygsel) does not in itself provide an adequate explanation for this mechanism, any more than the satisfaction of Strindberg's 'urge to utter everything his thought produced' (18:64) is simply a matter of his mental health. The elaborate undertaking, which situated language at the intersection of concealing and revealing, truth and lie, purity and filth, is far more deeply ambivalent. In Gothic Rooms, Dr Borg supplies another catalyst of the written word in 'modesty' (blygsamheten): 'Modesty forbids us to speak of it, therefore it is a good thing it is written, the printed word is silent and wounds no one' (40:25), and two related passages, one comparatively early, the other late, indicate the complexity of the tension that exists between the various constituents involved. In the section 'His Best Feeling' in A Blue Book, the written word is described as more than just the conventional attire of thought. At its purest, it becomes both a cloak of modesty and a vehicle of truth:

When a man writes a letter to a really good friend, or rather, to the woman he loves, he dresses up in holiday attire; it is beautiful of course, and in the silent letter, on the white page, he gives his best feelings.

One's tongue and the spoken word are so polluted by daily use that they could not speak out loud the beautiful things which the pen says silently.

This is not a matter of posing or posturing, there is no question of deceit when the soul one encounters in a correspondence is better than the one displayed in everyday life. A lover is not untrue in his letter. $\mathrm{He}$ does not pretend to be any better than he is, he becomes better, and at that 
moment he is better. In those moments he is true. They are the greatest life affords. (47:731)

Here Strindberg once again suggests that not only Babel but the very existence of language predicates man's fallen state - the imagery, for example, abuts such statements as the observation in The Great Highway on Aphrodite, born naked 'without even a vine leaf with which to cover herself, for clothes are only a consequence of the Fall of Man' (51:18). And yet, in its written form (and typically, Strindberg thinks in terms of a letter, the direct address to an absent addressee), language nevertheless represents the way in which social hypocrisy is circumvented and purity and truth achieved.

Similarly, a passage in The Son of a Servant, in which he discusses the discrepancies between Schiller's considered foreword to Die Räuber, and the furiously composed text itself, discloses the principle which permits him to accept the truth of written discourse:

Was Schiller being truthful when he wrote the play, and false, when he wrote the preface? Just as truthful on both occasions, for man is a divided being and appears now as natural man and now as social man. At his desk, in solitude when the silent letters were written down on the page, Schiller seems, like other, generally young writers, to have been under the influence, while at work, of the blind play of his natural instincts, without consideration for people's judgement, without a thought for the public or for laws and constitution. (18:277)

Although Strindberg could sometimes reject inspiration precisely because it seemed to indicate the author's absence from the words he wrote ('How then could one dare to depend upon a writer's words, when he has written them down in a condition of partial insanity... His mind has gone its own way, and when it has arrived at the end, the writer is not there with it' (16:54)), he normally accepts 'that the writer in his fever is led in the right direction' (VII:103) and subscribes to the notion of inspiration as a privileged discourse, one that is authentic and full. It cuts through social circumlocutions and facilitates a return to the truthful, prelapsarian discourse of natural man. In such moments language incarnates the self. It is not something distinct from the writer who uses it, and no longer an instrument open to abuse. It reveals the writer because language and self coincide.

Perhaps the most incisive comment on all these references to whiteness, purity, shyness, silence, and solitude, was passed, however, in another context, by Charles Darwin. When Darwin came, in The Expression of the Emotions in 
Man and Animals, to review 'The Nature of the Mental States which induce Blushing', he observed: 'These consist of shyness, shame, and modesty; the essential element in all being self-attention... It is not the simple act of reflecting on our own appearance, but the thinking what others think of us, which excites a blush..$^{49}$ Moreover, as Christopher Ricks points out, in Keats and Embarrassment, "the word "self-attention" had become the supreme subject and animus for the artist. ${ }^{50}$ And the self-attention which Strindberg bestows on himself is, as with Rousseau, of precisely the binary kind that Darwin identifies. For if, in their writing, they place themselves out of reach of an immediate interlocutor, who might interrupt, curtail, or misinterpret their spoken discourse, they live their lives before spectators, both fancifully, in their day-to-day affairs, and in time through the words they present to the reader's gaze.

On a level determined by commercial requirements, both writers obviously publicize, as well as publish, themselves. They wish to be seen and therefore exhibit their exceptionality. 'J'aimerois mieux être oublié de tout le genre humain que regardé comme un homme ordinaire, ${ }^{51}$ Rousseau remarks, in words that Strindberg might easily have substituted for the second epigraph to The Red Room: 'Rien n'est si désagréable que d'être pendu obscurément'. Or as a recent autobiographer, Ivar Lo-Johansson, observes: 'Anonymous notoriety is an impossibility. ${ }^{52}$

Furthermore, this dimension of Strindberg's activity is related to what might be termed presence via provocation, in which the reaction his words incite provides evidence that he has made his mark. Again, this is a very basic level indeed. As George Steiner comments, in his essay 'The Language Animal': 'We are so far as we can declare ourselves to be, and have full assurance of our asserted existence only when other identities register and reciprocate our life signals, ${ }^{, 53}$ and whether by polemic, in the shock aroused by the removal of verbal inhibitions, or in the resolve to strip himself naked, writing confers a feeling of ontological security on Strindberg. Nowhere, except perhaps in Rousseau, is a preoccupation with what others see in him so apparent as in Strindberg, and it is so central a factor because the opinion others have of him prevents him from being himself. It is to their intervention that he attributes what he diagnoses as his 'will-less character': "What will people say?" was then a constant refrain. And thus his self was eaten away, so he could never be himself, always depended upon the wavering opinions of other people, and never believed in himself, except on the few occasions when he felt his energetic soul work independently of his will' (18:15). Moreover, these privileged moments occur when, removed from the sight of his fellow men, Strindberg experiences the plenitude that writing affords: 'When I come home, however, and sit down at my desk, that's when I live', he declares, in Alone (38:155), while in the chapter of The Son of 
a Servant entitled 'He Becomes a Writer', he records how 'Now at last he had found his mission, his role in life, and his disjointed being began to find its form' (18:343). It is on paper, in writing, that his self takes shape.

Unfortunately, however, as Steiner goes on to remark, the communication of presence by language is both a negative and a positive accomplishment:

It is in the reciprocal nature of the statement of identity, in the need for echo, be it savagely contrary, to confirm one's own being, that lies the root of the Hegelian paradox: the need of one living entity for the presence of another, and the fear and hate engendered by that need..$^{54}$

Only by provoking a response will Strindberg know his words have been received, and what his militant strategies of attack and defence clearly demonstrate is the contingent nature of his undertaking. He requires another opinion, even as he resents and rejects it. But by making a virtue of the 'law of accommodation' and utilizing the multiplicity of the self which encounters with others help him to discern, Strindberg follows Rousseau in presenting his personality as a series of shifting facades, a sequence of roles in which he satisfies a desire to be interesting at any price and also avoids both the fear of being circumscribed within the character with which he is endowed by others, and the feeling of incompleteness or rejection evoked in the suggestion that he is 'overlooked' (förbigangen), a practice which suggests what R. D. Laing has termed 'meta-identities'. Reading Laing in the light of Darwin's far briefer observation, is to gain a substantial insight into the type of self-identity elaborated in Strindberg's (or Rousseau's) autobiographical writing:

In concreto, rather than in abstracto, self-identity ('I' looking at 'me') is constituted not only by our looking at ourselves, but also by our looking at others looking at us and our reconstitution and alteration of these views of others about us. At this more complex, more concrete level, self-identity is a synthesis of my looking at me with my view of others' view of me. These views by others of me need not be passively accepted, but they cannot be ignored in my development of a sense of who I am. For even if a view of another by me is rejected it still becomes incorporated in its rejected form as part of my self-identity. My self-identity becomes my view of me which I recognize as the negation of the other person's view of me. Thus 'I' becomes a 'me' who is being misperceived by another person. This can become a vital aspect of my view of myself. (E.g., 'I am a person whom no one really understands.') $)^{55}$

It is the 'misperception' in what others think of them which so often preoccupies both writers. Instead of the unstable but free relationship to others which most people tolerate, Rousseau and Strindberg experience another's gaze as primarily 
hostile. Rousseau, as Jean Starobinski points out, regards himself as 'la victime d'un regard anonyme, d'un spectateur sans identité... le témoin hostile, qui n'est personne en particulier, devient virtuellement tout le monde... un OEil omniscient. ${ }^{56}$ Similarly, Strindberg, informed that the golden eye in a window of Klara Church which dominated the landscape of his early years is 'God's eye' (18:27), always feels himself under observation and later maintains that 'The eye of the ruler of the world (Världsstyraren) is not blind' (47:704). Thus, whether the observer he detects is Ibsen, in the act of appropriating his life as the material source for The Wild Duck or Hedda Gabler ${ }^{57}$ or 'The Invisible One' who keeps him 'under total supervision' (XII:286), his private life is always a public spectacle.

Confronted by others, therefore, Rousseau and Strindberg seem about to lose themselves: the image which they have of their identity is undermined and fretted away by the summary conception that others form of them. 'Lessence de mon être est-elle dans leurs regards?' Rousseau asks, ${ }^{58}$ while Strindberg reveals a recurring nightmare in which 'Someone who has lived alone goes out into the world and sees and hears. Then he discovers how everyone has created their own image of him. He sees in their expressions, hears in their words, how they have transformed him. When one of them speaks out loud and says what they think of him he finds it horrible. It is not him but another, although fashioned out of all his wickedness and that of the speaker. ${ }^{59}$

This is the real source of the anguish experienced by both Rousseau and Strindberg when the words in which they speak prove inadequate as a means of self-representation. 'Qu'il seroit doux de vivre parmi nous, si la contenance extérieure étoit toujours l'image des dispositions du cœur', ${ }^{60}$ Rousseau exclaims, in the Discours sur les sciences et les arts. As in Swedenborg, perfect communication would dispense with words, and when enlisted to reveal the true Jean-Jacques to his interlocutors, who traduce his image and transform his unique value into the kind of superficial, limiting category that Strindberg identifies with an 'automaton' or 'musical box', speech is wholly inadequate. 'Moi présent on n'auroit jamais su ce que je valois', Rousseau explains, and thus provides the context for his retreat to literature in order to 'rendre mon âme transparente aux yeux du lecteur. ${ }^{61}$ And the loss of confidence in the capacity of language to reflect the world and convey the perceptions of one individual to another, is in fact evident in its dramatic presentation to the reader (in whose eyes they are seeking to restore themselves) by means of the two paradigmatic scenes of lie and deception with which they commence their autobiographies. Just as Jean-Jacques discovered the impotence of the spoken word as a means of self-representation from his inability to lie when 'les apparences me condannoient', ${ }^{62}$ so Johan learns that telling the truth in a house where (as at Bossey) 'lies were punished without mercy' (18:16), 
is no guarantee that he will be accepted for what he knows himself to be. Whether from shyness, shame, or modesty, the discovery of the theft causes him to blush, and he then compounds the supposed crime by rebutting the accusation, thus discovering that the language to which he entrusts himself does not redeem him from these false assumptions. In short, both Strindberg and Rousseau find themselves miscast, and they go on to present the moment as irreparable. 'From that day on Johan lived in perpetual disquiet' (18:18), Strindberg declares; 'Dès ce moment je cessai de jouir d'un bonheur pur, et je sens aujourdui même que le souvenir des charmes de mon enfance s'arrête là, claims Rousseau. ${ }^{63}$ It marks an end of innocence, a close to early childhood, and the expulsion into the snares of language which repeats, on a personal level, something of the disaster of Babel - the loss of which both authors will spend a lifetime exculpating in writing. ${ }^{64}$

'But Johan blushes' (18:17). Even the feature which propels his fall seems to substantiate Darwin and demonstrate that the nature of Strindberg's selfattention is directed as much to what others think of him, as to himself. And from the conclusion to the first volume of The Son of a Servant and the Foreword to Miss Julie, via Vivisections, to the deliberations of $A$ Blue Book, he insists that a person's character exists largely as a construct in other people's minds, and that in fact 'firmness of character is characterlessness. ${ }^{65}$ This argument, fostered as it is by the analysis of his own emotional lability, encourages him to resist the one-dimensionality of the roles in which his contemporaries would confine him (and into which, he argues, in the essays 'Is Character a Role?' (27:617f), and 'Pose and Gesture' (47:679), so many of them congeal), and to reverse the conventional notion of character, whether in life or literature, with its stress on the qualities of firmness and consistency, and the positive moral connotations they imply. This is the view of the ironically named Blacksmith in The Great Highway, who has forged 'a real character' for himself and proudly boasts his resistance to change (51:46), and The Son of a Servant, written, as Strindberg informed Bonnier, to 'explore the whole concept of character - on which of course the whole of literature rests' (V:343), may be read as a defence of the inconsistent and changeable Johan against the prevailing ideal of the 1880 s and its point of departure in Ibsen's Brand:

Don't be one thing today, one thing yesterday,

And something quite different a year from now.

Be what you have to be

Wholly and completely, not

A little bit here and a little bit there. ${ }^{66}$

As Strindberg would argue, 'Simple minds always speak of contradiction and inconsistencies, but everything that lives is made up of elements that are not 
homogeneous, yet have to be opposites in order to hold together, like those forces which draw unlike to unlike' (47:792). Thus he praises Ophelia as 'an unconscious attempt to present the outline of a character with all the nuances that the vulgar call inconsistencies' (50:77), and stressed his own achievement in creating, in Miss Julie, a character so overdetermined by physiological, psychological, and circumstantial influences that she emerges as strangely free of the normally inhibiting Naturalist characterization, with its stifling fatalism. His conception of the characterless character, as embodied in Miss Julie, Erik XIV, or himself, is therefore an expression of the conviction, which acquaintance with the theories of Ribot and Bernheim only confirmed, that character is not one and indivisible but many and various, and that, however sensitive its portrayal, it would always elude complete representation. As he indicated, in a typical contemporary image:

Note how many frames must be taken in sequence by the cinema photographer to reproduce a single movement, and even then the image is blurred. There is a missing transition in every vibration. When a thousand shots would be needed for one arm movement, how many myriads would not be required to depict a human soul? The writer's delineations of human beings are for that reason only summaries, outlines, all of them imperfect and all half false. (50:77)

These difficulties notwithstanding, his own writing is largely concerned with retrieving a just image of himself from the bowdlerized versions put about by others. Superficially, he feels that people (and not only Ibsen) are continually reading and writing his life. And just as his enthusiasm for photography did not extend to the taking of unauthorised images of himself, so he did not wish to fasten in any one else's text. Particularly in the early 1890s, his letters are filled with suppositions of plots, both in life and literature, in which he figures. Guilty himself of speculating in the destinies of his acquaintances, he infers that they are likewise engaged, thus betraying his sense of being constantly the object of other people's attention, as well as of his own. But as Torsten Eklund has pointed out, his fears were not without foundation, for he appeared in Ola Hansson's Fru Ester Bruce (1893), Adolf Paul's story 'Med flaska och det ärliga ögat' (1895), parts of which were revived in Paul's memoirs of Strindberg in 1915, and Przybyszewski's Homo Sapiens (1895), as well as in Munch's paintings and lithographs. ${ }^{67}$ Undoubtedly, such attention contributed to the sense of persecution which dominates the early stages of the Inferno crisis, and on the way to the creation, in Inferno, of a formal narrative structure that would integrate the disparate parts of this experience, his letters already offer many preliminary drafts in the art of reclaiming his destiny from other hands; as he told Paul, in 1894: 'I have learned how to correct chance' (X:67). But 
the process is exemplified best by an earlier text, $A$ Madman's Defence, which according to its pseudonymous narrator Axel, was written to pre-empt the most terrible of all conceivable destinies, namely that his wife, Maria, would remarry or 'live sumptuously [with her Danish lesbian lover] on the income of my "collected works" and trace the story of my life as seen through the eyes of a hermaphrodite' (MD:245). He has to write the true narrative of his marriage in order to defend himself against the possibility of a false, literally perverse, account.

This specific anxiety is related to a general feeling that 'people demand he perform the role they have chosen for him, and in which he then easily remains stuck fast' (48:834). It is as if by 'rubbing up against other people... he had lost the best part of himself through the law of accommodation.... [and] developed into a characterless, smooth, sociable person' (24:164). Thus, like Borg in By the Open Sea, of whom this is said, he experiences a recurring need 'to go in search of himself in isolation' (24:102). For as the partner of yet another Maria observes, 'We are afraid of losing our identity through the assimilating power of love, and therefore we sometimes have to break out in order to feel that I am not you' (37:136), and Strindberg's own response to intercourse of any kind is described by Assir, in The Isle of the Dead, when, stung by the suggestion that he 'doesn't exist at all', he retorts: 'Oh yes I do, because I react to others; and if I stopped doing that, the others would engulf me with their egos, with their opinions, their fancies. They would kill me with their wills, I would cease to exist, and the whole struggle of my life has been to preserve my self!' ${ }^{68}$

This sense of the precariousness of individual identity, with which Strindberg invests so many of his characters, is strikingly similar to the condition that R. D. Laing defines as 'engulfment', whereby the subject's basic security is so low that practically any relationship, however tenuous, threatens to overwhelm him. Even their response is often as Laing charts it:

The main manoeuvre used to preserve identity under pressure from the dread of engulfment is isolation. Thus, instead of the polarities of separateness and relatedness based on individual autonomy, there is the antithesis between complete loss of being by absorption into the other person (engulfment), and complete aloneness (isolation). ${ }^{69}$

This illuminates Borg's repossession of himself, 'isolated like a cosmic splinter', in By the Open Sea (24:29), and accords with the image that Strindberg circulates of himself in his last years: 'In the end he cannot go out, because people's glances alight on him, penetrate his skin, and poke into his heart' (48:834). And this rediscovery or concentration of himself 'within his own skin' (37:144) is effected in his case by writing, which is an expression of 'the instinct of differentiation, not to be another but to be oneself (VII:247). In fact 
the formulation 'His position was false, and he wanted it to be immaculate (ren)' in The Son of a Servant (18:117), is typical of the impulse to withdraw into the silence and purity of the printed word. For in extreme situations, personal intercourse threatens to overwhelm Strindberg and his characters with the impurity, dirt, and disorder associated in Armageddon with Dimona. According to Max, in Gothic Rooms, it is especially in a double-bed that one loses one's self, one's self respect, one's human dignity. It is there one sells one's soul and learns the art of concealment' (40:296), and Strindberg is haunted by the possibility that he can even be polluted in his absence by a woman's ability to draw him into intercourse with other men. As he writes in The Occult Diary (6 September 1901) of Harriet Bosse: 'Unknown men pollute me by the glances with which they pollute her... If she is free and has an affair with another man, she hands over my soul and transfers my love to a man, and thus causes me to live in a forbidden relationship with a man's soul or body or both!' Or as Max pithily observes: 'They seek her, and find him, for he is within blocking the way' (40:210).

In fact this spectre is often raised in the 1900s. Ten days later, he records how Harriet 'goes about befouling my soul which during my Inferno period I washed fairly clean. It is as if, through her, I entered into forbidden relationships with men and other women' (this last phrase being added above the line), and similar fears are expressed in A Blue Book (46:179), Queen Christina (39:251), and the third part of To Damascus, where the Tempter explains, 'I was so constituted that I couldn't go out with her in company because I felt she was soiled by other men's glances... the whole of my existence began to be perverted into a spiritual concubinage with strange men - which was against my nature which has always craved woman!' (29:327), as well as in He and She, and in the fascination with which he variously related the circulation among a group of friends, of what numerous letters and a late Vivisection describe as everyone's 'Aspasia', a figure derived from the emancipated Norwegian, Dagny Juel, whom Strindberg first encountered in the company of Edvard Munch, and later lost to the Polish writer, Stanislaw Przybyszewski. Indeed, the matter is never far from his attention, for to elide the distinction between men would, like the erasure of all difference between man and woman, be a violation of the 'natural' order his writing is engaged to distinguish and maintain: 'if differences do not keep them apart, then the whole world would be perverse' (40:267). Thus he tells an unknown correspondent that 'for the man a love affair is in fact only a delight in so far as it is between two souls, and every interference from outside seems like filth' (VII:29), warns his friend Bengt Lidforss that 'screwing a man's wife is perverse! It's a mixing of seed!' (IX:357), and explains the jealousy felt by Johan for his successor in the favours of his housekeeper on Kymmendö as a necessary act of mental purification: 
He had deposited pieces of his soul in this girl's: he had treated her as an equal, interested himself in her destiny... Furthermore, he had mixed his blood with hers, given impulses, tuned the fine strings of his nerves in harmony with hers, so that they already belonged to one another, and now along came someone else and poked his nose in where he had tried to create order, cut off his electrical contact, retuned the strings, spoiled his work and brought disharmony to his soul, which he had been careless enough to graft on to a woman's... (19:91)

In this context, therefore, where to 'wash oneself clean' (tvätta sig ren) and exonerate oneself (rentvå sig) are related terms on which Strindberg often lays stress, his committal to the purity of the silent paper effects both a cleansing and a redemption from the loss of self incurred through contact with others. It is employed to preserve both his person and the categories with which he confronts the world from violation, and it is thus not entirely fanciful to see, in the solitary act of writing, an onanistic retreat that rescues him from the coition of spoken discourse, enables him to master the other in private, and seems to offer an opportunity of keeping himself intact. Indeed, at times he appears to infer such a link himself. In writing to Ola Hansson in 1889, he rejects Maudsley's diagnosis of masturbation as a symptom of degeneration, and relates it to a symptom of 'the strong ego which does not want to sacrifice its talent for dubious children who would become his competitors' (VII:247), and in his portrait of the artist, Alrik Lundstedt, speechlessness in the face of women leads him to retreat to the private delights of his organ loft. ${ }^{70}$

Sometimes casually, in the coarse vein of Flaubert or the Goncourts, at others drawing the kind of parallel between sexual and verbal ejaculation that Balzac espoused, writing is in any case frequently related to sexuality by Strindberg. 'I acknowledge that a woman's embrace resembles the joys of birth when a new thought is hatched |or| a beautiful image wells up', he concedes, to Littmansson, 'but the unsatisfied sexual instinct and half-hunger transforms itself into mental power. (I have written my strongest pieces - Miss Julie and Creditors - in 30 days during enforced celibacy.)' (X:130). As Asta Ekenvall has pointed out 'For him sexual and mental production were closely related. ${ }^{71}$ Miss Julie he calls '1st Class Seed' (X:214) with which he has 'fertilized' others, and he regards his writing in general as a godlike procedure wherein he has 'begot with myself like Zeus a whole Olympus, fools and imposters, saints and children' (X:130). Moreover, the implication is almost always the same; if in Black Banners, Dr Borg argues that the sexual act should be effortless, like inspiration, Strindberg repeatedly identifies writing as an alternative form of intercourse, one in which he demonstrates his prodigious potency and the fertility of his invention which peoples a world. Sometimes the two appear to preclude each other ('My former wife could do what she wanted,' he tells 
Littmansson (X:131), 'but I also wrote what I wanted, and therefore my spirit was never dominated, only my sexual impulses'), but this is not necessarily so, unless the writer is a woman, in which case Strindberg generally regards her as physiologically infertile ('with us the marriages of women who write usually distinguish themselves by their sterility' (VR:101)), since she encroaches upon a male domain and so sows (or reaps) only disorder. 'One ought not to demand of the artist, who gives, that he should become a woman - that he should receive, ${ }^{72}$ Nietzsche remarks, in a summary of contemporary ideology, and, as Ekenvall continues, 'for Strindberg active sexuality and mental curiosity become synonymous, become potency, a proof of masculinity, while in the same way sexual and mental passivity become specific female characteristics. ${ }^{.73}$ Thus Strindberg appropriates the scriptor's role in life and in literature, and boasts of 'everything I have shaken out of my britches! although Sweden was stony ground! Novels and poetry, plays both good and bad, histories of Sweden and China, and four kids, a fifth on the way, and two wives' (IX:372).

The claim is well founded. And yet Karl-Åke Kärnell is surely correct to argue that 'on the intellectual and literary level, he assigns himself the dream role of the potent man, the vigorous procreator, which periodically at least he feared he could not manage in marital intercourse. ${ }^{34}$ It is this which gives the edge to his insistence that Sweden's hostility towards him depends upon its hatred of 'fertility' that Viktor Rydberg's jealousy as a writer is 'the unfruitful woman's terrible envy and hatred of the fruitful' (IX:372), and that publishers either demand he 'writes chastely (castratedly)' or insist on cuts, which is to 'remove my testicles' (IV:240). For he wrote to convince his fatherland that he was potent, and he wanted every word to be published so that 'sterile and sexless Sweden will see what a fecund spirit they hated because he was fecund and they were sterile (VI:297).

Strindberg's consolation is therefore that he 'puts other people's brains into molecular movement with my pen' (IX:374), that he 'recognizes (his) children' in another writer's book, or sends a theatre audience home 'pregnant with my mind's seed' (X:130), and he readily conceives himself the father and author to other texts besides his own: 'Strange that I should always be the Father who provides the spermatoza, fertilizes' (XI:146). But in the cluster of images concerning suggestion, seeds of thought (tankefrö) and molecular movement in the sphere of the mind, which dominates his writing in this register, the tension between engulfment and self-preservation remains a factor, even when the discourse to which Strindberg commits himself is written and not spoken. For if Hedda Gabler delights him because it seems to bear the features of The Father and Creditors (thus he writes exultantly to Birger Mörner and claims paternity: 'Observe how my seeds have fallen into Ibsen's own brain pan - and sprouted! now he bears my semen and is my uterus!' (VIII:205)), the process 
could easily be reversed. On one occasion, his 'mental life has received in its uterus a tremendous ejaculation of seed from Friedrich Nietzsche, so that I feel full like a bitch in my belly' (VIII:112), and he is continually on guard against being cast in the woman's role wherein he would become another man's creation and so contravene what he regarded as 'natural' law. For woman is created by man (as The Lady in To Damascus is given a name by The Unknown): the man 'fills her with his content and can find a good helpmate in this, his second self, which he has trained to be like himself (17:164), and the image of 'the bitch' with which Strindberg compares himself under impregnation from Nietzsche is otherwise evoked in situations of degenerate sexuality, in Miss Julie, where Diana forsakes her breeding and her chastity and anticipates her mistress by coupling with 'the gatekeeper's pug' (23:120), or in the material from an unknown correspondent that contributed something to the conception of Creditors, and of which he remarks: 'Anna's character is interesting, a modern degenerate, who pays no heed to her stock but like a bitch, copulates with several' (VII:29). Hence Strindberg is circumspect in his relationships: 'Why don't I write to him myself?' he remarks to Edvard Brandes, of Georg: 'Because I am afraid. Afraid of him as of all fertile spirits, afraid as I was of Zola, Björnson, Ibsen, of being made pregnant with their seed and giving birth to another's progeny' (VI:134).

In the 'Battle of the Brains', which these passages delineate, each hears, in company, or in the presence of books, 'human voices bearing words, which wanted to eat their way through his ears into his brain, shed their seeds, and then like weeds choke his own sowing and transform the field he had cultivated with so much effort into a natural meadow resembling all the others' (24:77). Encouraged by the experiments of Charcot and Bernheim, and by an earlier tradition deriving from Mesmer and transmitted, in a form well known to Strindberg, by Hartmann, who claimed that 'the fundamental phenomena of mesmerism, or animal magnetism, are at length looked upon as scientifically accredited, ${ }^{75}$ Strindberg embraced the idea that people easily imprint themselves on one another. In A Madman's Defence, Axel sees the features of the Danish woman embossed on Maria's face (MD:246); in By the Open Sea, Borg interprets his Maria as a 'chaos of past stages, these bits of roles which she had successively played in life, masses of shifting reflexes from men, whom she had tried to win and adapted herself to' (24:114); and in later prose works, Strindberg assumes the Romantic-Realist tradition of Balzac, Hoffmann, and Dickens, in which a character's inner feelings are imprinted upon his surroundings. Inanimate matter is endowed with life. It displays a person's innermost thoughts, and bears legible traces of the past which under the informed, interpretative eye of the Narrator in The Roofing Feast or the compiler of $A$ Blue Book, it also lays bare as a text in which to read the hidden 
self. As the latter observes: 'When a married man comes home from a ball with his wife, he ought to look at her handkerchief, which she has fingered the whole evening. Then he would doubtless see with whom she would most like to have danced' (46:188).

Where the relationship is one between man and woman, Strindberg's ideas are often in keeping with those of other nineteenth-century writers. Michelet, for example, in L'Amour, held that 'La femme fécondée une fois, imprégnée, portera partout son mari en elle. Voilà ce qui est démontré. Combien dure la première imprégnation? Dix ans? vingt ans? toute la vie? Ce qui est sur, c'est que la veuve a souvent du second mari des enfants semblables au premier. ${ }^{76}$ And prompted by Prosper Lucas's Traité philosophique de l'hérédité naturelle, both Zola and Daudet regarded woman as tied to her first lover by indissoluble physiological bonds. He imprinted on her an ineradicable trace which might be passed on even to the features of her children by other men: 'Elle ne l'aima jamais avec passion; elle reçut plutôt son empreinte', Zola writes, in Madeleine Férat, and again, 'Lorsque Madeleine s'était oubliée dans les bras de Jacques, sa chair vierge avait pris l'empreient ineffaceable du jeune homme. ${ }^{37}$

When Strindberg sees in woman an empty vessel, a clean slate, or a vacant place awaiting the creative intervention of man ('All the beauty we see in her', Dr Borg remarks, in Gothic Rooms (40:299), 'is only our own projections upon her white and empty screen'), his discourse is therefore not unduly singular. But it becomes more individual when, in the urgency of his desire to abrogate the scriptor's role, he continually reveals himself alert to the way in which character is engraved, traced, or inscribed by one subject on another. What fascinates him, moreover, is not the traditional concept of a secure, indelible inwardness, but the possibility of many and various editions, scripts which can be erased and traces superimposed, one upon the other. People, in short, represent white pages, which the stronger covers with his style. 'He really confirms the idea I share with the philosopher of a tabula rasa,' the Narrator says, of his companion, in the story 'The Battle of the Brains', 'and now, after he is newly washed, I feel a great desire to write in my handwriting on his tablet' (22:140-1). Gustav, in Creditors, reminds Tekla of their first meeting when 'you were a little, lovable child; a small slate on which your parents and your governess had scribbled a few lines which I had to scratch out. And then I wrote new texts, to my own liking, until you thought you were ready written' (23:256-7), and the image recurs, years later, in To Damascus III, when the Tempter speaks of the wife from whom he has been parted as no longer the virgin surface he had once known but 'another: she, my unblemished white sheet of paper was scribbled all over with scrawls; her beautiful, clear features were tuned in harmony with the satyr-like visages of strange men' (29:327). In this instance the experience with which Strindberg is concerned reflects 
conflicts in his marriage to Harriet Bosse, which are also charted in The Occult Diary and imaginatively explored in The Roofing Feast (44:49), but what he writes only confirms an earlier occasion when, in 1876, he wrote to Siri von Essen of his fear that Wrangel 'will scrape out every word I wrote in your soul' (I:350).

Character is thus presented as a fluid coalescence of numerous texts, the product of many discourses, and Strindberg indicates that people become copies or transcripts of one another. They not only bear the ineradicable imprint of their society and age (Naturalism's milieu and moment), and the genetic trace of their birth; they are also marked with the imprint of each other's personalities, and his modernity is nowhere more apparent than in his perception of the complex intertextuality of identity. The self, he tirelessly affirms is compiled from many discourses, 'a composite resumé of parents, educators, friends, books' (18:436). But this has several implications for his autobiographical project. Firstly, common to the whole complex of imagery centred on tankefrö and the inscription of traces, there is a desire on Strindberg's part to be his own source, the author of himself, and progenitor of his own life. And this project is in turn interfaced with the abiding anxiety regarding his own possible lack of identity, an anxiety which can only be dispelled by writing but which, paradoxically, the very act of writing reinforces and prolongs.

The situation is intricate. In the first place, it is the white page which captivates Strindberg's imagination. For without writing he is threatened by emptiness (tombeten) or vacuity (tomrummet), an emptiness which he repeatedly evokes, and into which he fears he might disappear. Superficially, the notion is commonplace, as when, in The Isle of the Dead, he revives (probably inspired by Locke's image of the pre-mnemonic mind as a white paper, void of all characters, in Book Two of An Essay Concerning Human Understanding) the trope of memory as a book: 'If for a moment you could lose your memory, you will become like a book with white pages, less than a newborn child, and would have to begin again!'78 This recalls the scene at the graveside of Struve's child, in The Red Room, where

Falk remained bent in thought over the grave and stared down into the depths; at first he saw only a square of darkness, but gradually a light speck emerged, which grew and took on a definite form. It was round and shining, white like a mirror. It was the uninscribed tablet on the young child's coffin which shone through the darkness and reflected only the unbroken light of heaven. (5:255-6)

What haunts him is the spectre of an unwritten character. He is afraid of leaving no real trace, of writing so faintly that, as he in fact implies in the account of a vanish acquaintance in $A$ Blue Book (46:86-7), he would disappear, and it is 
therefore he finds it so natural, in the vivisection, 'Soul Murder', to compare the suppression of a manuscript to murder, since 'a blank space (tomrum) thereby arises in a writer's soul' (22:194). The missing text represents a lacuna through which the writer vanishes, and Strindberg's angoisse before the empty page is thus not the common dread of being unable to write, but trepidation in the face of a surface that does not signify - or rather, signifies only too clearly an absence. The white page is in fact a void which the agoraphobic Strindberg must populate, and his writing obeys an impulse to people it with words, an impulse that is betrayed in the unlikely context of the historical tale, 'At the Bier Side in Tistedalen', where he contrasts the fertility of the writer with the impotent warrior king, Charles XII, who lived in a perpetual aversion to providing his country with a successor to the throne'. As the doctor exclaims, over the dead king's corpse:

Imagine, this hand, which wielded the rapier so proudly, could not coax a light quill pen across a sheet of smooth paper... then the mechanism refused to obey, then it wavered and shook, as if he had got agoraphobia (torgsjuka) in the middle of the white field. Indeed, he said himself he got dizzy when he had to cross the sheet of paper. But it wasn't only that; his thoughts, which ought to have marched forward in straight columns, tripped one another up, trampled on one another's toes, and once when I read a letter to his sister, which he asked me to correct, the words lay there in long strips, tangled up as if one saw the whole muddle of his mind unwound... (12:383)

In this episode of Strindberg's long-running conflict with a figure whose role, throughout his career, approximates to that of a Yeatsian opposite, the pen is matched against the sword, and word against deed. But in the image of the king's 'torgsjuka', the text discloses a hidden identity between the two antagonists. For in both The Son of a Servant (18:316) and 'Deranged Sensations' (27:601), as well as by implication in the story, 'Short Cuts', Strindberg describes his own agoraphobia. Here, however, he attributes the condition to his opponent, so asserting once more the supremacy of the new aristocracy of the pen and nerves over the appearance of manliness decked out in the uniform of tradition. As such the passage resumes hostilities in a conflict that has been fought on this ground in, for example, The New Kingdom and A Madman's Defence. ${ }^{.79}$ More immediately, however, it maintains that character is clearly written as characters by those courageous enough to traverse 'the white field' of paper which, to be sure, is readily turned by Strindberg's pen into a field of battle.

Rather than establish a character which is single and indivisible, however, writing fosters multiplicity. If in general 'the danger of a long life is that the many roles begin to get muddled up, like an actor's wigs and costumes when 
he moves' (47:681), then the writer's life, with its multitude of assumed or invented roles which provide 'reincarnations already here [on earth]' (46:113), is especially vulnerable to the dispersal of identity. The danger is illustrated by Alrik Lundstedt's delight in metaphor, which transforms him into a Gyntian metamorphoser, a man in constant danger of fatally displacing himself, while the figure of Askanius, in the late novel, The Scapegoat, who 'shed his skin, and changed his character and face every ten minutes' (44:183), portrays the artist as a protean but anonymous creature who, in spite of a compulsion to confess himself (44:119), remains ultimately unknown and unknowable. ${ }^{80}$

Strindberg is in fact continually aware of the Keatsian paradox in which it is lack of identity that characterizes the poet. But unlike Keats, who could appreciate that 'the poetic Character... has no self', and accept that 'Not one word I ever utter can be taken for granted as an opinion growing out of my identical nature, ${ }^{81}$ Strindberg found this possibility the cause of endless misgivings. Although he was sometimes able to transform the fact 'that the poet's life was a shadow life, that he had no self, but only lived in other selves' into yet another instance of his own fertility ('But is it so certain that the poet lacks a self because he does not have only one? Perhaps he is richer, and possesses more than the others' (18:436)), he was more inclined to regard his situation as a kind of sleepwalking in which he could easily mislay himself: 'It seems to me as if I am walking in my sleep; as if poetry and life had got mixed up... Through so much writing my life has become a shadow life; it seems to me I no longer walk on earth but am suspended weightlessly in an atmosphere not of air but of darkness' (VI:298). Condemned by the practice of writing to address himself to an absent (or an imaginary) interlocutor, the indirectness of the mediation to which he entrusts himself causes Strindberg to slip into a world of hallucination where he is disembodied and overwhelmed by a dreamlike sense of unreality. Thus, in those moments when, as it were, he comes to himself, he doubts his identity. In one of the many notes for the short fable, 'Jubal Without a Self' (38:93-101), whose significance it is easy to overlook, unless its provisional title, 'Johan Without a Self', is recalled, he observes how 'Those who change their names, lose themselves', and in another, he once again speculates on the consequences of a life-time of role playing: 'The man who denies his identity and is thereby punished by losing himself.' Moreover, in so far as Zachris, in Black Banners, embodies Strindberg's own deeply-rooted feelings of guilt about the parasitic nature of his writing, it is precisely in a lack of identity that the writer's role playing, or facility at identification, is located. Zachris, 'a selfless jelly, an unorganised matter that lived like a truffle on the roots of others' (41:211), 'had an enormous emptiness (tomrum) to fill and his impressionability was unbounded. He ate people, ate up their accomplishments, fed upon their private means, and possessed the 
ability to enter other lives... so that he confused his person with other people' (41:48).

To confuse oneself with another, however, is the destiny from which autobiographical discourse is employed to secure the subject. It is to become another's shadow, whereas the autobiographer wishes to relate his own story, in his own language. Indeed, confronted by the common patrimony of the language into which they are forced to translate themselves when they present themselves to another, autobiographers frequently speculate on the possibility of a means of utterance that is uniquely their own. Thus Rousseau recognizes the need for 'un langage aussi nouveau que mon projet, ${ }^{83}$ and his role as the model autobiographer is perhaps nowhere more apparent than in this desire to secede from common discourse and inaugurate his own. What he has to communicate is so singular that even to instate himself within the common vulgate by means of a radical, particular choice of vocabulary and syntax (the style with which he leaves his signature upon the corpus of language), appears too shallow a gesture. He does not want an ideolect, but his own unrepeatable language.

But this vision of discovering what another copious autobiographer, Ivar Lo-Johansson, calls 'the only right words' ${ }^{84}$ the conclusive words which body forth 'that full utterance which through all our stammerings is of course our only and abiding intention', ${ }^{85}$ founders upon one of the fundamental principles of post-Saussurian thought, namely that 'La propriété privée, dans le domaine du langage, ça n'existe pas.' ${ }^{\prime 6}$ The language in which the autobiographer seeks to convey himself not only precedes him; it is also held in common with other individuals, a shared circuit of exchange in which the newcomer finds the available words already inhabited. As Mikhail Bakhtin describes it

When each member of a collective of speakers takes possession of a word, it is not a neutral word of language, free from the aspirations and valuations of others, uninhabited by foreign voices.... The word arrives in his context from another context which is saturated with other people's interpretations. His own thought finds the word already inhabited.... When one's own personal 'final' word does not exist then every creative plan, every thought, feeling and experience must be refracted through the medium of another person's word, style and manner, with which it is impossible to directly merge without reservation, distance and refraction. ${ }^{87}$

But if the language at the autobiographer's disposal is embedded in the conventions of his time, is beset by the contingent emphasis of the moment, and permeated by the social and intellectual inferences of the age, it is also by composing himself in words and behaving as if the lacunary nature of consciousness were an uninterrupted, reclaimable flow, that he is compelled 
to wonder at his own reality. For in the continual search for self-definition, he seems regularly to disappear into the text of which he is nominally the master, where he becomes not transparent but a property of the language in which he inscribes himself. As the intimate, lived experience passes into language, it is mediated by the interrelationship between the signifiers, which come in time to stand for the experience itself. As language displaces the past and person it is employed to represent (and the notion of presence is ironically evoked by the faculty of language as representation, the fabrication of a copy that replaces the original), it establishes a metaphorical narrative that secretes and accretes meanings which surpass and undermine the intention of the author and elaborate a narrative framework that subsumes the particles of autobiographical fact implanted in it. Private experience enters the domain of language and then the formal contract of literary genre, where it is enhanced with conceptual figures and stylistic devices, and becomes an item in the institution of literature, in Strindberg's case, a material deposit of late nineteenth-century social, intellectual, and literary history, which contributes in turn to the production of other discourses, both autobiographical and critical. It is the signifier which moves into the foreground; the empirical facts of the life are transformed into artifacts; sequence is endowed with meaning and condensed into design, and the truth or falsehood of the material, so challenging a question for earlier discussions of the genre, becomes very much a secondary matter once Freud establishes that what is spoken or written and not what might have happened, is what matters. The act of stripping oneself naked in public therefore remains what it has always been, a metaphor, and the autobiographer remains, for all his effort, behind the discourse he leaves after him. The author, indeed, becomes a figure of the text.

If, therefore, the defining words continue to elude him (if he remains, as Beckett suggests, 'unnamable'), then this search for an appropriate language transforms the autobiographer into a kind of language machine, compelled to produce ever more words on his own behalf as each verbal account, having proved itself incomplete, leaves him still 'The Unknown' or 'Not I'. The autobiographer's dilemma is indeed an intricate one. If his purpose is to return to his origins and establish identity by uncovering the continuity of his personality over the passage of a significant period of time, then he is committed to narrative. For it is by means of narrative that the individual establishes a relationship with the world, which helps him to recover coherence in the face of evanesence, subdue contingency by revealing a hidden causality or pattern, and create the image of self-identity through time that enables him to act. Life can only be recuperated as a plot and a spectacle, as a story which the individual claims for his own, and in which he establishes himself as the other whom he observes making his way through the confusion and accidents 
of the past towards the present. This is the process which has been so finely described by Freud in his analysis of 'Screen Memories', where he elaborates the essential distinction between the acting and the recollecting self:

In the majority of significant and in other respects unimpeachable childhood scenes the subject sees himself in the recollection as a child, with the knowledge that this child is himself: he sees this child, however, as an observer from outside the scene would see him... Now it is evident that such a picture cannot be an exact repetition of the impression that was originally received. For the subject was then in the middle of the situation and was attending not to himself but to the external world. ${ }^{88}$

But in spite of the inevitable rupture between the recollected and the recollecting subject, it is by the imaginative process of story-telling, in the enchainment of the text, that the autobiographer shapes his life. In fact Rousseau dates the unbroken consciousness of himself from his earliest reading, and in Mme la Tribu's lending library he discovered other exemplary plots by means of which he could create a kind of specular image of himself through identification and reverie, and Ivar Lo-Johansson, too, records the transition from a time when memories were not yet enchained, and the past had not become a narrative composition, to a more consciously structured existence when he 'began as though playing with building blocks to fabricate with the aid of my memory connections between events which I had not even bothered about before... I consciously 'invented' people and occurrences, and I made a kind of poetry or sketches out of them. ${ }^{89}$

The autobiographer is therefore confined to a life in language, according to criteria which are often sustained by the conventions of the alternative, dominant genre, the novel, where language also fabricates a person, and narrative condenses a life into a destiny. And as Lacan writes, of the analogous discourse of the patient in analysis, by recounting a past event 'he has made it pass into the verbe, or more precisely, into the epos by which he brings back into present time the origins of his own person. And he does this in a language which allows his discourse to be understood by his contemporaries, and which furthermore presupposes their present discourse. ${ }^{90}$ Thus, while the language in which the autobiographer composes his narrative allows him a point of purchase which permits him to locate himself, either by assuming a personal pronoun which is open to everyone (and which, as Francis Hart has pointed out, is chosen to perform the structural role in the narrative for which it is variously designed $)^{91}$, or as a proper name, which 'guarantees the unity of our multiplicity [and] federates our complexity of the moment and our changes in time, ${ }^{92}$ each entry into what Lacan has termed the symbolic order, where the subject attempts to situate himself, represents an inevitable surrender to 
the vast, supra-personal archives of the word and a rupture of the self-narrator along the lines described by Freud in 'screen Memories', but now inscribed in his use of language.

Even the image which the writer conceives of himself, therefore, becomes to some extent a misprision, differ in only in scale to the misconceptions conceived of Rousseau and Strindberg in the paradigmatic scene of their respective autobiographies. For the ' $\mathrm{I}$ ' who writes is both the subject of the discourse and the personal, historical object of his own verb, at once present and absent in the 'I was', where he is another. He is always represented by a stand in (his appearances, as the Unnamable remarks, in Beckett's novel, 'must have been put in by other parties' $)^{93}$ and as Bakhtin observes:

Even if he is the author of an autobiography, or of the most truthful of confessions, the writer nevertheless remains, as their creator, outside the world depicted in them. If I tell of (or write about) an event which has just happened to me, I, as the teller (or writer) of this event, am already outside that time-space in which this event has occurred. It is impossible to identify absolutely myself, my 'I', with that 'I' of which I am telling as it is to lift myself up by the hair. ${ }^{94}$

Since the self is only constituted in language (and thus, when written, requires the attention of a reader to re-animate it, as Lacan's many suggestions that the signifier is that which represents the subject for another signifier insistently imply), ${ }^{95}$ it is a verbal construction essentially different from the events it recovers, as St Augustine was already aware: 'with regard to the past, when this is reported correctly what is brought out from the memory is not the events themselves (these are already past) but words conceived from the images of those events. ${ }^{96}$ Autobiography is therefore not something that exists in the past, awaiting narration. It is the story told, structured, and organized with all the devices of literature, and what it does not accomplish is the denuding of the self held out by the illusory promise of a unique, full language. It remains a reflection, the site of a temporal and logical organisation by which the writer produces, from the dialectic of his narcissistic identifications with the external views of himself in which he fears capture, an opaque image which, for the moment, he imagines to be true.

These are factors in writing the autobiographical discourse of the self which become increasingly prominent the further Strindberg proceeds with his project. Although initially he avoids the first person and its enticing promise of identity, the better to analyse himself in the spatial and temporal distance afforded both by the third person and by the mantle of a name (his forename, Johan, and the significant act of nomination in which he christens himself 'The Son of a Servant', and thereby assumes a destiny on the plane of myth), 
he is not unaware of the way in which he becomes a creature of the text, that he is in fact engaged in an inexhaustible cycle of attempts to capture the self. Indeed, he could find in one of his mentors, Ribot, a precise statement of the contradictory nature of his undertaking: 'le vrai moi est celui qui sent, pense, agit, sans se donner en spectacle à lui-même; car, il est par nature, par définition, un sujet; et pour devenit un objet, il lui faut subir une réduction, une adaptation à l'optique mentale qui le transforme et le mutile. ${ }^{.97}$ The individual's conception of himself was, Strindberg knew, an abstraction, a specular image which gave back the contour of whatever technique is used to capture it ('Where does the self begin, and where does it end?' he asks, in Jardin des plantes, 'Is the eye adapted to the sun? Or does the eye create the phenomenon called the sun?' (27:354)). Notwithstanding the implied consent to prevailing nineteenth-century notions of character growth and development, which the basic linearity of the narrative method in the first volumes of 'the history of a soul's development' (en själs utvecklingshistoria) would seem to sustain, it therefore becomes clear that Johan is not encompassed by any of the images presented of him, and that the promise implicit in this narrative mode, that eventually the subject will be seen to have become himself, that with the turn of the page he will suddenly come into sight, will not be honoured. 'The self is not any one thing; it is a conglomeration of reflexes, a complex of instincts and desires which are alternately suppressed and unleashed' (18:218), he concludes, at the end of the first volume, and when he finishes the fourth, he is no closer to a final statement. He had embarked upon the autobiography because he found, when looking at himself, only 'a motley jumble which lacks substance, which changes its form according to the observer's point of view and which has perhaps no more reality than the rainbow, which is there to be seen, but which doesn't exist' (19:277). Now, having brought the enterprise to the moment of writing a conclusion, he can only gesture towards the words themselves as the problematic and by no means final version of himself:

Where does the truth for which he was seeking lie? It lies here and there in the thousand printed pages; look them up, collect them, and see if they can be summarized, see if they are valid for longer than a year, five years, consider if they have a chance of being so, when that requires their receiving general acceptance. And do not forget that the truth cannot be found, since it is always in the process of continual development. (19:278)

'Development' (utveckling) thus becomes the negation of the being he set out to find. The 'true' self, he discovers, is no fixed image but a set of tensions, mutations, dialectical oppositions, which take up the discursive formations or determinacies that impinge upon the individual and make of him a complex montage of ideas, feelings, attitudes, gestures, misconceptions, and 
which cannot be conveyed as a single, evolving trace, however copious and circumstantial, but as the product of many traces which cover and recover one another, as in the engraved complexity of the design upon the vase from Benares, whose surface of interlacing lines and intricate patterning provides him during the experimental re-exploration of the past in which he engaged during the Inferno period, with a more sinuous and elaborate model for the record of the self he resolutely continued to pursue. 